\title{
Improving approaches to assessing the recreational potential of land
}

\author{
Elena O. Ushakova ${ }^{1,2, *}$, and Evgeny I. Avrunev ${ }^{1}$ \\ ${ }^{1}$ Siberian State University of Geosystems and Technologies \\ ${ }^{2}$ Novosibirsk State Technical University
}

\begin{abstract}
Land market transformation and shift of development directions in the Russian Federation and its regions require to revise formed spatial planning scheme, and as a consequence, land transfer from one category to the other, parcelling out of land for various types of recreational use and determinate of investment attractiveness of land for infrastructure recreational objects building. Contemporary territory administration should base on rational use of land nature potential as significant resource of the economics of sustainability. This type of economics can show such stable indicators as the population and the consumption level and its scale doesn't exceed ecosystem bearing capacity. The article considers the main factors which influence the level of land recreational potential, approach to the assessing the land recreational potential for regional and industry planning and revealing of investment attractive land for recreation and tourism as the perspective direction of sustainable development. The authors revealed attractive areas that can be use more effectively for land recreational potential bases on studying of the Novosibirsk region land fund and growing of population demand for recreation and health recovery in this region as the permanent residence which changed due to the COVID-19 pandemic and high risks of travel to other countries.
\end{abstract}

\section{Introduction}

The need for recreational activity organization in the regions grew, in particular, in the permanent residence during the COVID-19 pandemic while the borders were closed. Considering the focus on the trips within and between regions in the tourism development in the nearest future, probably, it will come to investment attractiveness of recreational property. This fact let us forecast the growth of the investor interest in plots of land selection which good for the construction of recreational facility objects. Actual proposals of land for recreational and tourist activity are limited, so it requires to review the spatial planning scheme of municipality and expand land area of recreational use by transfer such land from one category to another. It is important to consider physiographic conditions and environment such as soil composition, vegetation type, water bodies and other factors and conditions which determine favorable land use for recreation and tourism organization, simultaneously, factors that decrease the land recreational potential as level of environmental pollution,

${ }^{*}$ Corresponding author: eo_ushakova@mail.ru 
location on the territory or near the allotted land of industrial objects, unauthorized dumps and transboundary pollutants transport.

At present current approaches to the assessing the land don't allow to consider a number of factors which determine its recreational potential level. This potential should be used for establishment of new spatial planning scheme because it can influence on priorities of socioeconomic development in regions and provide economics with growth points through the satisfaction of needs in recreation and health recovery among local citizens.

Therefore, it is important to allow recreational potential in spatial planning scheme and determination of land investment attractiveness for the recreational objects building. The main goal of this article is to reveal land recreational potential in contemporary conditions and to form a new approach to the assessing the land recreational potential as the resource of the economics of sustainability.

\section{Materials and methods}

Tourism and recreation consider as priority directions of socio-economics development in many regions of Russian Federation in contemporary conditions that promotes growth of the investment attractiveness for the recreational use. The main points of the study have embodied in regulations of the Russian Federation and in some scientific studies which reveal factors influence on land recreational potential, land assessment and its recreational potential, territorial planning and organization of the recreational and tourist activity[1-7].

At present, there is no method for fair evaluation of various recreational use land for the construction of the recreation value objects. Many factors such as political and legal, economic, social and other factors influence on the real estate value. First of all, it necessary to consider ecologic factor for the assessing the land recreational potential. This factor includes environment conditions are determined by natural phenomenon or effect of its components and set the level of qualitative condition of land and its improvement. Obviously, environmental friendliness of the territory influence on the land value.

We might emphasize positive and negative ecological factors, for instance, attractive natural landscape, the availability of recreational objects, forests, lakes and rivers, clear reservoirs, absence of industry etc. will be the factors that increase the land value whereas water, air or land pollution by chemicals, destruction of plantings, availability of industry will decrease the land value.

As all resources, using in recreation and tourism related to the land, i.e. they determined by the borders of tourist and recreational complex and territorial administration, the accounting of recreational land elements realizes by it. Certain land estimates on the basis of physiographic conditions and environment climatic conditions that favorable for recreation and tourism development. Estimation of recreational potential in a larger scale in dealing with spatial planning scheme in municipalities and the subjects of the Russian Federation.

It should be noted that factors' significance will differ in various types of recreational land use. For instance, recreational land with environmental friendliness and natural landscapes use for the construction of recreational objects (suburban hotel complexes, hostels, health centres, rest houses etc.). It is necessary to use land as recreation and scientific or ecological tourism areas are next to specially protected natural area. The higher indicator value of recreational potential the higher land value.

Thus, this approach to the valuation of the recreational land potential allow for objective factors for the development of recreation and tourism spheres as natural conditions, environmental friendliness, comfort of natural and climatic conditions, contrast, balneological resources, specially protected natural area, uniqueness, attractiveness of resources, recreational strain on landscape units, degree of territory development for recreational goals, infrastructure characteristics, technological capabilities, tourists needs, 
municipal and regional administration interests, interests of local citizens and tourists and etc. $[1,8,9]$. Consideration of these factors promotes to reveal perspective plots of land for recreational objects construction with natural resources opportunities of territory and its investment attractiveness.

This study determines main factors as availability and development of infrastructure and transport, safety, uniqueness, attractiveness of natural objects, environmental friendliness, natural landscape capacity and picturesque which influence on the land value for recreational use.

\section{Results and discussion}

It is important that it should be done component-wise recreational land value with available elements of landscape units. We can divide territory into areas with more high and low level of recreational potential for cadastral valuation while it is necessary to introduce correction coefficients with local components of potential for market valuation of land.

All districts of the Novosibirsk region were combined by the potential level according to indicators of territory natural-resources potential calculation results. Chanovsky, Toguchinsky, Chistoozyorny, Novosibirsk, Zdvinsky, Iskitimsky and Dovolensky Districts became leaders according to the calculations. These districts have the highest recreational potential for development basis on natural and ecological background and geographic location. Nevertheless, to determine investment attractiveness for the construction new infrastructure objects and economic efficiency of recreation and tourism development in municipalities it is necessary to consider as natural and climatic resources and elements of the historical and cultural and socio-economics potential.

According to recreational potential value of main administrative divisions in the Novosibirsk region we revealed the most attractive districts that have preconditions for various kinds of recreation and tourism organization. We use indicators of infrastructure availability, resource potential elements availability for campers and tourists and the level of consumer demand to define the attractiveness of the territory. District clustering with various degree of investment attractiveness allows to distinguish high-priority territory and territory with insufficient land potential for investment in infrastructure objects.

We offer certain recommendations to develop the territory of districts in the Novosibirsk region on the basis of ranking and studying the land potential structure.

The comparison of the results of ranking in the value of recreational potential with clustering on the level of general potential shows that one district is in the group with high attractiveness for recreation and tourism development. This is the Novosibirsk region. Being close to the center, sanatorium complex, tourist bases, children recreation camps are settled near the Novosibirsk Reservoir and high transport availability define the most favorable preconditions and appropriate specialization. The land value here for the recreation use is the highest in the region.

The group with high attractiveness for recreation and tourism includes Chanovsky, Toguchinsky and Iskitimsky Districts. These are favorable territories for recreation activities development but the remote location decreases the attractiveness compare with Novosibirsk district. Considering high recreational opportunities of this territory it needs to develop. It becomes necessary to realize the tourism, recreation and investment projects program support, construct the new infrastructure objects, stimulate small business and promote the recreational opportunities of the territory.

We would like to notes that Chistoozyorny and Zdvinsky Districts are in the group with low investment attractiveness for recreation and tourism development due to incomplete infrastructure, especially, concerning the transport infrastructure. 


\section{Conclusions}

The proposed approach to estimation of the land recreational potential can be used for decision making in territorial planning, spatial planning scheme of municipalities and as a base for land parcelling for recreational use and land transfer from one category to the other. These recommendations can use for the correction current methods of land value that ready for the construction of the recreational objects.

To develop the recreational activity on the perspective territories it is necessary to expand land area for recreation, to attract investors to construct the recreational infrastructure objects, allocate land areas for the rest areas and increase the transport and information availability.

\section{References}

1. A.V. Belov, L.P. Sokolova, Geography and Natural Resources, 3(31), 228 (2010)

2. P. Ashouri, Sh. Fariyadi, Journal of Environmental Studies, 3655, 1 (2010)

3. A. Shamsoddini, Open Journal of Ecology, 80 (2015)

4. Gadakh Bharat L., Jaybhaye Ravindra G., Nalawade Pravin M, International Journal of Research in Geography (IJRG), 1(1), 8 (2015)

5. D. La Rosa, M. Spyra, L. Inostroza, Indicators of cultural ecosistem for urban planning: a review. Ecological Indicators, 61, 74 (2016)

6. V. Kurdyukov, I. Avlasenko, L. Avlasenko, S. Kanurny, E3S Web of Conferences. 13. "13th International Scientific and Practical Conference on State and Prospects for the Development of Agribusiness, INTERAGROMASH, 14003 (2020)

7. A.P. Karpik, E.I. Avrunev, A.E. Truhanov, International Journal of Applied Engineering Research, 39601 (2015)

8. E.O. Ushakova, M.E. Tsoy, V. Y. Shchekoldin, IOP Conference Series: Earth and Environmental Science, 204, 012046 (2018)

9. E.O. Ushakova, A.V. Dubrovsky, V. N. Moskvin., S.A. Vdovin, IOP Conference Series: Earth and Environmental Science, 459, 062049 (2020) 